\title{
DRIS Use on Apple Orchard Nutritional Evaluation in Response to Potassium Fertilization
}

\author{
Gilmar Ribeiro Nachtigall \\ Embrapa Grapes and Wine, Bento Gonçalves, Brazil \\ Antonio Roque Dechen \\ University of São Paulo, College of Agriculture Luiz de Queiroz \\ (ESALQ), Piracicaba, Brazil
}

\begin{abstract}
The aim of this work was to use the diagnosis and recommendation integrated system (DRIS) method to evaluate the nutritional status of an apple orchard, cv. Gala/MM106, at Vacaria, State of Rio Grande do Sul, Brazil. Treatments consisted of four levels of annual maintenance potassium fertilization. Data on fruit production and fruit pellicle color were restored from 1995 to 2000, as well as the data on leaf macro and micro-nutrient concentrations. The DRIS indices and nutritional balance index (NBI) for each nutrient were determined using three methods: Beaufils, Jones, and Elwali and Gascho. The results showed that (i) the NBI, calculated from the generated norms, were negatively correlated negative correlated with productivity and fruit coloration, and (ii) the DRIS method, described by Elwali and Gascho and using the $\mathrm{F}$ value, was the most suitable for apple tree orchards, because the NBI values obtained with this method best indicated the nutritional status of the plants and provided a more accurate nutritional diagnosis.
\end{abstract}

Keywords: DRIS, foliar diagnose, Malus domestica, potassium fertilization

Received 8 December 2005, Accepted 29 October 2006

Address correspondence to Gilmar Ribeiro Nachtigall, Embrapa Grapes and Wine, P. O. Box 130, Bento Gonçalves 95700-000, RS, Brazil. E-mail: gilmar@cnpuv. embrapa.br 


\section{INTRODUCTION}

Among the macronutrients, potassium $(\mathrm{K})$ is one of the most important for apple tree production; it is sometimes ranked second or third in relation to nitrogen $(\mathrm{N})$ and calcium $(\mathrm{Ca})$, depending on the situation (Nachtigall, Basso, and Freire 2004). Potassium occurs as a free ion within the plant and plays several important functions, some of them involved in the water movement, such as the regulation of cell turgidity (stomata opening and closing), carbohydrate transport, and transpiration, among others, which greatly affect fruit quality (Marschner 1995).

The analysis of leaf tissues in fruit culture has been very useful for the evaluation of the orchard nutritional status and fertilization recommendations (Marschner 1995); plant nutrient concentrations are a result of interactions among several factors involving soil nutrient availability and plant absorption (Mengel and Kirkby 2001). Several methods for nutritional diagnosis using foliar analysis have been proposed and used, including the methods of critical value, sufficiency ranges, and the diagnosis and recommendation integrated system (DRIS).

DRIS has been developed and proposed by several researchers (Beaufils 1973; Sumner 1986; Walworth and Sumner 1987) and generates indices of nutritional balance in the order of nutrient limitations. It also integrates interactions between nutrients and other factors. The DRIS norms established for a specific crop are usually applicable to the same crop in any area of cultivation (Beaufils 1973). DRIS has been successfully applied to many annual and perennial crops (Fallahi and Righetti 1984; Walworth and Sumner 1987; Mourão Filho and Azevedo 2003; Goh and Malakouti 1992).

There are several studies regarding the application of the DRIS method to apple tree orchards; results have been reported in Canada (Parent and Granger 1989), Hungary (Szücs Kállay, and Szenci 1990; Szücs and Kállay 1990), New Zealand (Goh and Malakouti 1992), and India (Singh, Awasthi, and Sud 2000). All these studies agreed that the DRIS method was appropriate for the nutritional diagnosis of apple tree orchards. In Brazil, the first study on the DRIS method applied to apple trees was developed by Nachtigall (2004), which succeeded well for this fruit nutritional diagnosis.

The objective of this research was to use the DRIS method to evaluate the nutritional status of apple trees in response to $\mathrm{K}$ fertilization and compare its efficiency with the nutrient sufficiency range criterion.

\section{MATERIAL AND METHODS}

This research work was accomplished with data obtained from a long-term field experiment carried out during 1991-2000, with K fertilization rates applied prior to planting and yearly thereafter. Apple scions of the Gala cultivar grafted on MM106 rootstocks, free of viruses, were planted (spaced 
$2.5 \times 5.0 \mathrm{~m}$ ) in 1991. The experimental area was located at Vacaria, State of Rio Grande do Sul, Brazil $\left(28^{\circ} 30^{\prime} 00^{\prime} ; \mathrm{S}, 50^{\circ} 42^{\prime} 21^{\prime} \mathrm{W}\right.$, altitude $\left.955 \mathrm{~m}\right)$, in a soil classified as a Humic Xanthic Hapludox (Streck et al. 2002). Soil samples from $0-20 \mathrm{~cm}$ deep were submitted for laboratory analyses and showed the following characteristics: clay, $540 \mathrm{~g} \mathrm{~kg}^{-1}$; organic matter, $58.8 \mathrm{~g} \mathrm{dm}^{-3} ; \mathrm{pH}$ (water 1:1) $=5.8$; phosphorus $=5 \mathrm{mg} \mathrm{dm}^{-3}$; aluminum $=0.4 \mathrm{mmolc} \mathrm{dm}^{-3}$; and calcium + magnesium $=2.7 \mathrm{mmolc} \quad \mathrm{dm}^{-3} ; \quad$ potassium $=1.15 \mathrm{mmolc}$ $\mathrm{dm}^{-3}$." INSTEAD OF “(water 1:1) $=5.8 ; 3 \mathrm{p}=5 \mathrm{mg} \mathrm{dm}^{-3} ; \mathrm{A} 1=0.4$ mmolc $\mathrm{dm}^{-3}$; and $\mathrm{Ca}+\mathrm{Mg}=2.7$ mmolc $\mathrm{dm}^{-3} ; \mathrm{K}=1.15$ mmolc dm$^{-3}$.

The experimental design was in randomized complete blocks in an arrangement of split plots, with the initial potassium fertilizer $(0-50-$ $100 \mathrm{~kg} \mathrm{ha}^{-1}$ of $\mathrm{k} 20$ in planting) as the main plots and the annual potassium fertilizer (0-50-100-150 $\mathrm{kg} \mathrm{ha}^{-1}$ year-1 of k20) as the subplots, with four replications and three usable plants per experimental unity. Standard field management procedures were used during the apple orchard growth and formation, concerning weed, pest, and disease control.

Data on fruit production and fruit pellicle color were recorded from 1995 to 2000. Leaf samples (100 leaves/replications) were collected from the medium third of year's branches, 15 weeks after full bloom, for chemical analysis. Leaf macro and micronutrient concentrations (nitrogen, phosphorus, potassium, calcium, magnesium, boron, copper, iron, manganese, and zinc; $\mathrm{N}$, $\mathrm{P}, \mathrm{K}, \mathrm{Ca}, \mathrm{Mg}, \mathrm{B}, \mathrm{Cu}, \mathrm{Fe}, \mathrm{Mn}$, and $\mathrm{Zn}$, respectively) were determined according to procedures described by Freire (1998). Fruit color was graded from 0 to 5 $(0=$ color absence; $5=$ maximum red color $)$ according to the fruit pellicle red color intensity.

The DRIS indices were calculated, using (for the choice of nutrient ratio order) the criterion of the largest variance ratio between the populations of low and high productivity (F value), described by Letzsch (1985) and Walworth and Sumner (1987) and using three forms of nutrient function calculation according to Beaufils (1973), Jones (1981), and Elwali and Gascho (1984).

The nutritional balance index (NBI) was calculated through the sum of the index absolute values generated per sample and obtained for each nutrient; the median nutritional balance index (NBIm) was calculated by the sum of the index absolute values per nutrient obtained for each sample, divided by the number of nutrients considered in the calculus.

The DRIS norms, used for the evaluation of the nutritional status of apple trees in response to $\mathrm{K}$ fertilization, were established using data obtained from 70 commercial orchards from the Brazilian apple producing areas located at Campos de Cima da Serra (RS), Alto Vale do Rio do Peixe (SC), and Planalto Serrano (SC) (Nachtigall, Basso, and Freire 2004).

The diagnosis and evaluation of the apple tree foliar nutrient concentrations were accomplished using the range of nutrient concentration criterion, adopted in the States of Rio Grande do Sul (RS) and Santa Catarina (SC) (Nachtigall, Basso, and Freire 2004), and DRIS, calculated according the three procedures already described. 
The diagnosis consistency was tested by comparison of the (1) range of nutrient concentration criterion, considering three ranges (deficiency, sufficiency, and excess), (2) DRIS, using the method proposed by Wadt (1996), with three ranges established from the DRIS nutrient index $\left(\mathrm{I}_{\mathrm{Nut}}\right)$, and the median nutritional balance index (NBIm), assuming the ranges

$$
\begin{aligned}
& \text { Deficient }=\mathrm{I}_{\text {Nut. }}<0 \text { and }\left|\mathrm{I}_{\text {Nut. }}\right|>\text { NBIm, } \\
& \text { Normal }=\mid \mathrm{I}_{\text {Nut. }} . \leq \mathrm{NBIm} \text {, and } \\
& \text { In excess }=\mathrm{I}_{\text {Nut. }}>0 \text { and }\left|\mathrm{I}_{\text {Nut. }}\right|>\text { NBIm. }
\end{aligned}
$$

The calculations of DRIS indices, NBI and NBIm, were performed using the software Microsoft Excel ${ }^{\mathrm{TM}}$. The efficiencies of the three methods were evaluated through linear regression between NBI and fruit productivity data, using the general linear models (GLM) of the SAS software (SAS Institute 1985).

\section{RESULTS AND DISCUSSION}

Leaf $\mathrm{K}$ concentration was positively correlated $(\mathrm{R} 2=0.76, \mathrm{P}<0.01)$ with the relative production ( $\%$ of annual maximum), and fit a quadratic regression model (Figure 1). Maximum productivity was obtained for the average leaf $\mathrm{K}$ concentration of $14.9 \mathrm{~g} \mathrm{~kg}^{-1}$, a value considered within the normal range (12 to $15 \mathrm{~g} \mathrm{~kg}^{-1}$ ), according to the criterion of sufficiency range for the apple tree (Nachtigall, Basso, and Freire 2004). A marked productivity reduction was observed for $\mathrm{K}$ concentrations lower than $10 \mathrm{~g} \mathrm{~kg}^{-1}$. Ernani, Dias, and Flore (2002), studying the response of apple trees to K application in the soil over 7 years, observed increasing fruit productivity with the increasing

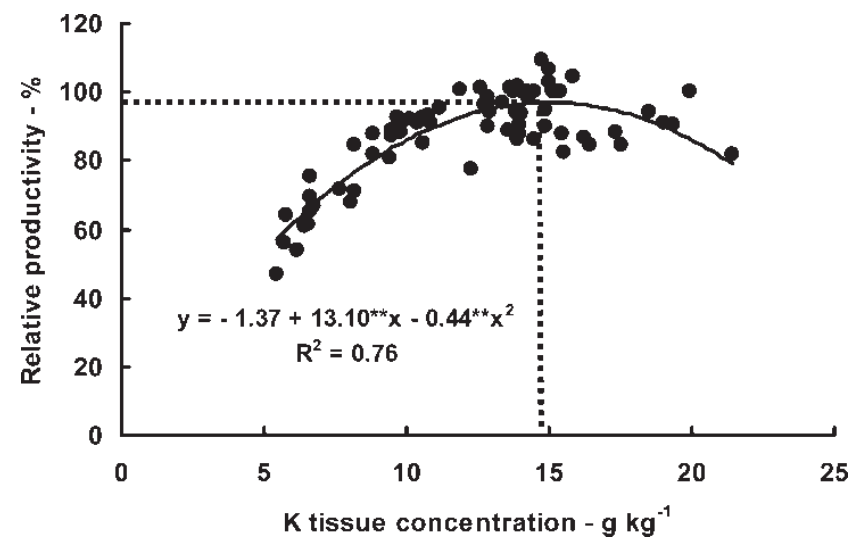

Figure 1. Relationship between the leaf K concentrations and the relative fruit productivity of an apple orchard, Gala cultivar, in response to potassium fertilizer (average data of 6 years). 
soil and leaf $\mathrm{K}$ concentrations. These authors found maximum productivity related to leaf $\mathrm{K}$ concentrations of approximately $10 \mathrm{~g} \mathrm{~kg}^{-1}$, which is considered insufficient for modern apple orchards. Such low leaf K concentrations obtained for high-producing trees was attributed to the sink/source power demand, that is, high nutrient translocation from leaves (source) to the fruits (sink strength) during fruit development.

Positive correlations were obtained $\left(\mathrm{R}^{2}=0.94, \mathrm{P}<0.01, \mathrm{R}^{2}=0.87\right.$, $\mathrm{P}<0.01$, and $\left.\mathrm{R}^{2}=0.92, \mathrm{P}<0.01\right)$ for Beaufils, Jones, and Elwali and Gascho indices, respectively) between leaf $\mathrm{K}$ concentrations and DRIS indices, which fit quadratic regression models (Figure 2). These results indicated that the DRIS indices for $\mathrm{K}$ were strongly dependent on $\mathrm{K}$ leaf
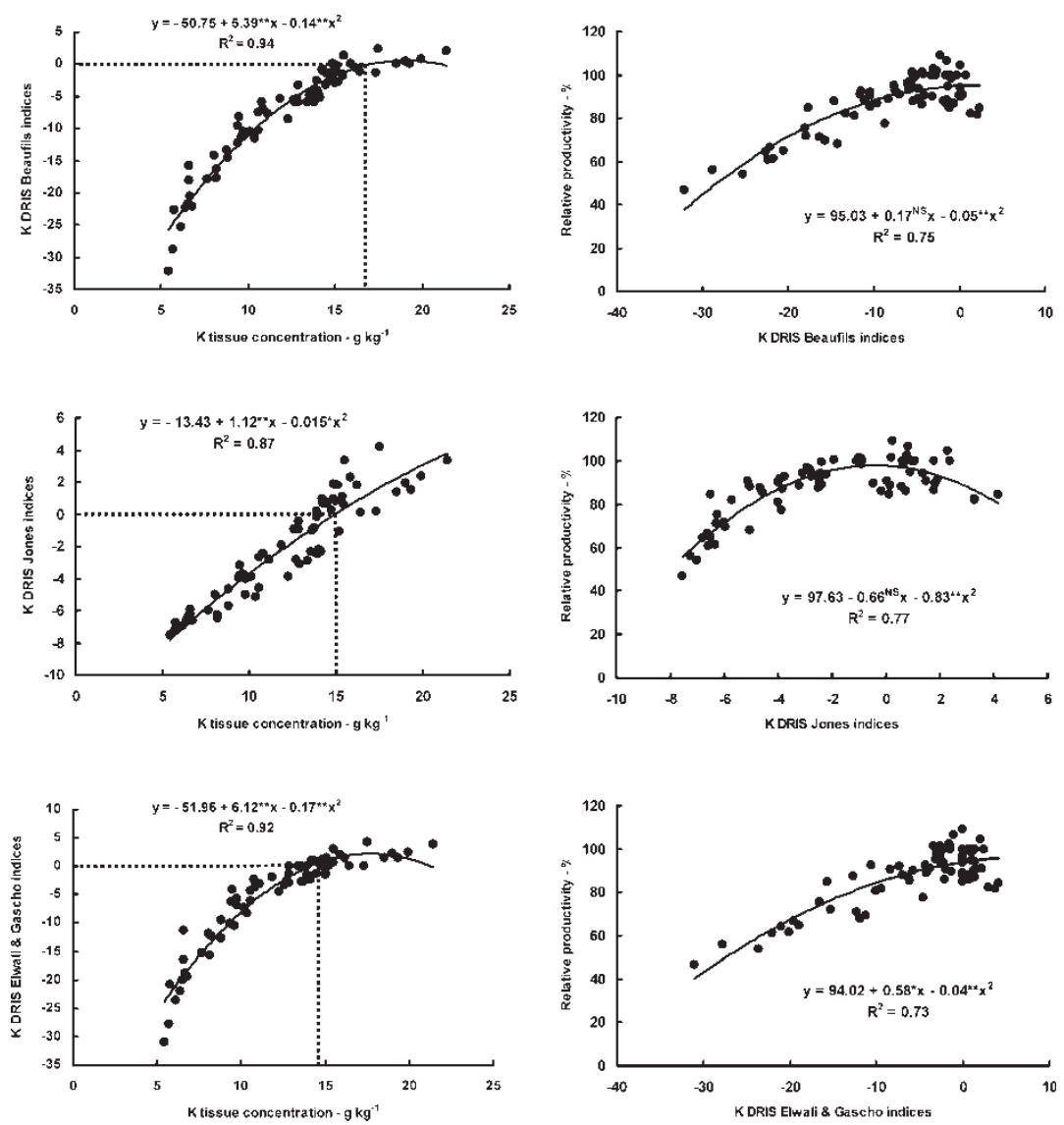

Figure 2. Relationships between the leaf K concentrations and K-DRIS indices and between the relative fruit productivity and K-DRIS indices, calculated according to Beaufils, Jones, and Elwali and Gascho methods, for an apple orchard (Gala cv.) treated with potassium fertilizer (average data of 6 years). 
concentrations. The point of nutritional balance, defined for DRIS, was within the adequate leaf $\mathrm{K}$ concentration defined by the criterion of sufficiency range (Nachtigall Basso, and Freire 2004), except for the Beaufils (1973) method. This latter method resulted in higher $\mathrm{K}$ concentration for the nutritional balance point, greater than the range considered adequate for apple orchards, probably because the original equation of Beaufils (1973) generates DRIS indices that emphasize the most deficient nutrients.

Positive correlations were observed between the relative fruit productivity of apple trees (Gala cv.) and the K-DRIS indices; the data fit quadratic regression models for the three methods used $(\mathrm{R} 2=0.75$, $\mathrm{P}<0.01, \mathrm{R}^{2}=0.77, \mathrm{P}<0.01$, and $\mathrm{R}^{2}=0.73, \mathrm{P}<0.01$ ), for Beaufils, Jones, and Elwali and Gascho indices, respectively) (Figure 2). The highest productivity was obtained when leaf $\mathrm{K}$ concentrations were within the suitable range according to criterion of sufficiency range for apple orchards and the nutritional imbalances indicated by the DRIS indices were related to decreases in productivity. The results indicated that, for the Beaufils and Elwali and Gascho methods, the closer to zero the DRIS index for K, the greater the productivity of the apple tree culture.

However, the method of Jones resulted in a wider range of k-DRIS indices for the highest productivity values. Additionally, the relationship from the Jones method was similar to the one observed for the relationship between leaf $\mathrm{K}$ concentrations and the relative fruit production (Figure 1). Figure 3 shows the
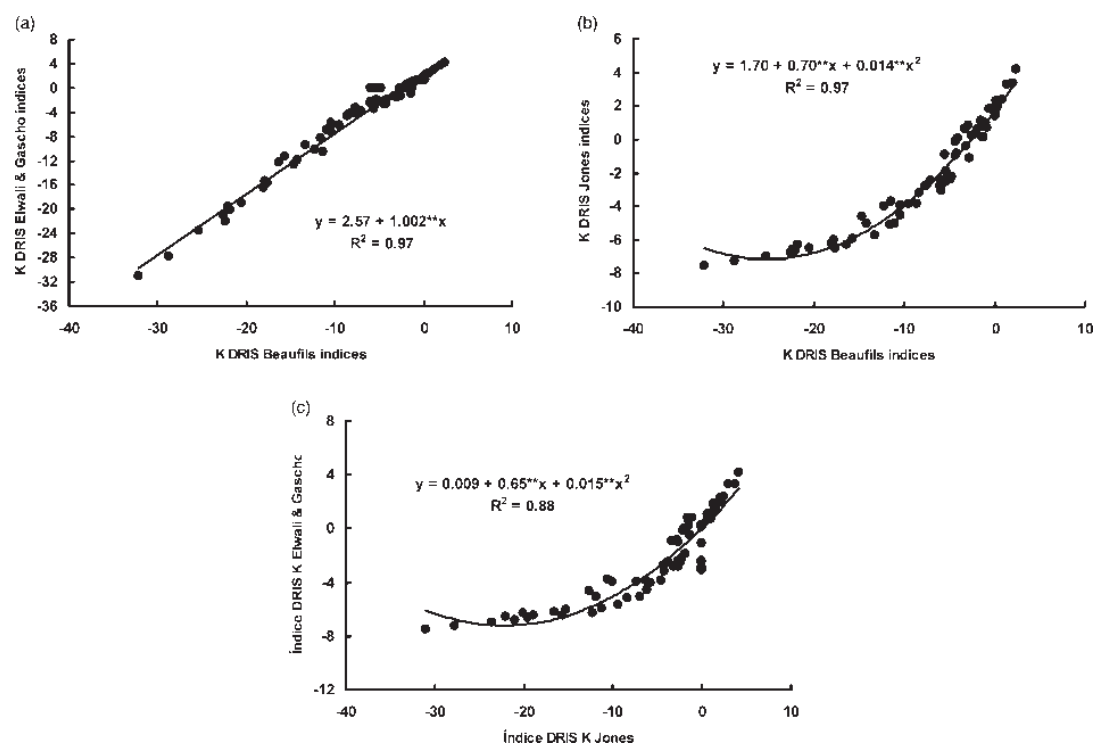

Figure 3. Relationship between Beaufils, Jones, and Elwali and Gascho methods for K-DRIS index calculation for an apple orchard (Gala cv.) treated with potassium fertilizer (average data of 6 years). 
relationships between the K-DRIS indices obtained by the three methods. DRIS indices obtained by both Beaufils's and Elwali and Gascho's equations were linearly correlated $\left(\mathrm{R}^{2}=0.97, \mathrm{P}<0.01\right)$. Nevertheless, DRIS indices obtained by Jones's equations showed quadratic relationships with the ones obtained by the two other methods, indicating that the Beaufils and Elwali and Gascho methods generated DRIS indices that emphasize the more deficient nutrients.

The nutritional balance index (NBI) pattern closely followed the theoretical model and fit a quadratic regression equation inversely related to the fruit production (Figure 4). Higher productivities were related to lower NBI values $\left(\mathrm{R}^{2}=0.46, \mathrm{P}<0.01, \mathrm{R}^{2}=0.22 \mathrm{~ns}\right.$, and $\left.\mathrm{R}^{2}=0.55, \mathrm{P}<0.01\right)$ for Beaufils's, Jones's, and Elwali and Gascho's equations, respectively). Similar results were
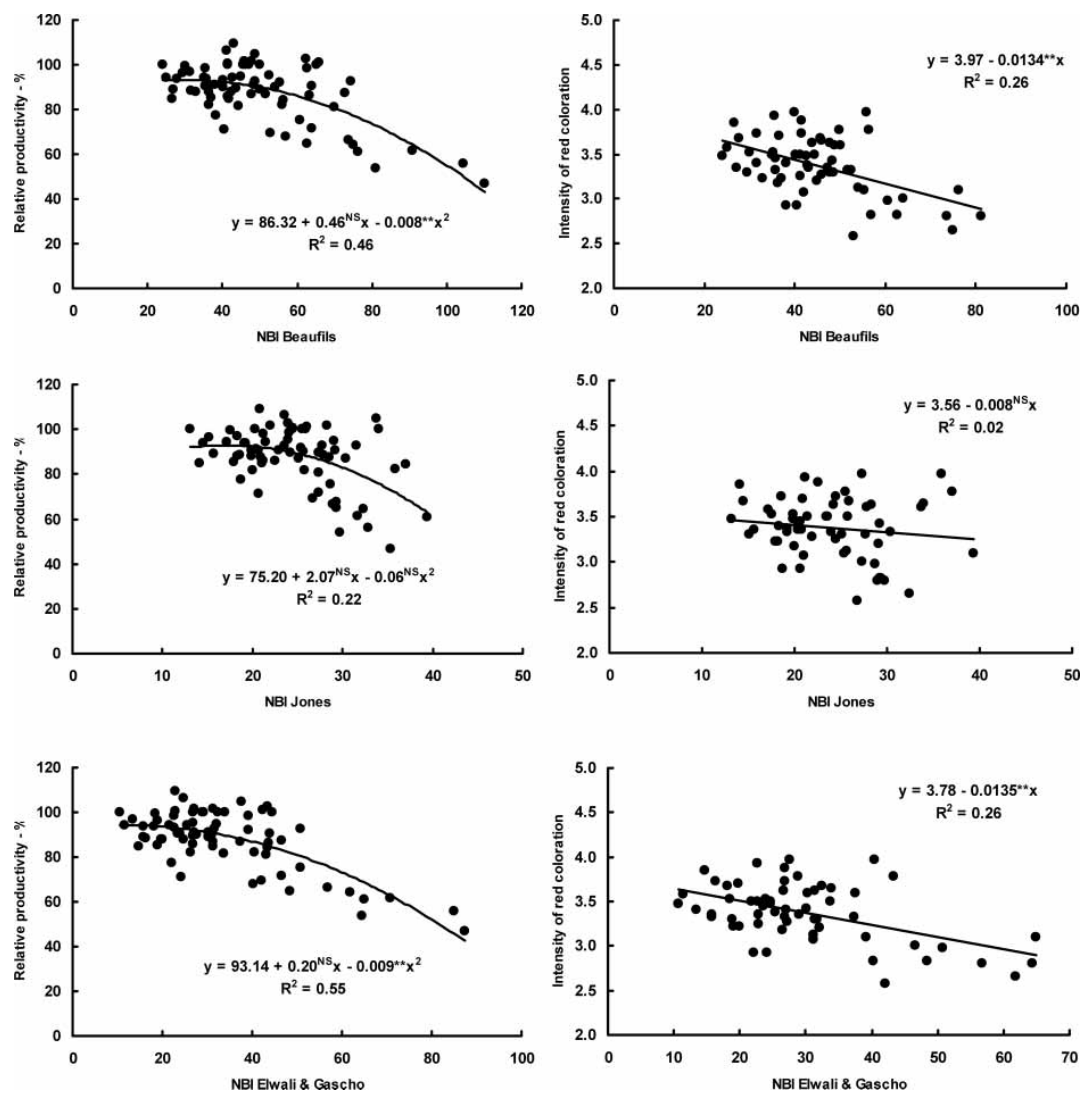

Figure 4. Relationship between the nutritional balance index (NBI) and the relative fruit production and between the nutritional balance index (NBI) and the fruit pellicle red color intensity based on K-DRIS indices calculated according to Beaufils, Jones, and Elwali and Gascho methods, for an apple orchard (Gala cv.) treated with potassium fertilizer (average data of 6 years). 
obtained by Silva, Nogueira, and Guimarães (2003) when evaluating the use of DRIS to assess the nutritional status of coffee plants (Coffea arabica L.) in response to $\mathrm{K}$ fertilization. The significant regression coefficients $(\mathrm{P}<0.01)$ indicated there were correlations between DRIS indices and productivities, except for the indices calculated by Jones's equations. However, working with citrus in the State of São Paulo, Santos (1997) obtained different results and pointed out the higher efficiency of Jones's method for the calculation of DRIS indices, which was also corroborated by Nick (1998) for coffee plants and by Mourão Filho and Azevedo (2003) for 'Valencia' orange trees.

The NBI was inversely related to the pellicle fruit red color intensity and fit a linear regression model (Figure 4). Highest fruit color intensity was related to the lowest NBI values, with significant regression coefficients for both Beaufils's and Elwali and Gascho's equations $\left(\mathrm{R}^{2}=0.26, \mathrm{P}<0.01\right)$ but not Jones's method $\left(\mathrm{R}^{2}=0.02 \mathrm{~ns}\right)$.

The efficiencies of DRIS and the sufficiency range criterion methods were compared using the percentage of nutrient diagnosis values that were agreed by both methods. For this, the number of nutrient-deficient leaf samples (leaf concentrations $<$ sufficient values) and the number of nutrient-sufficient and nutrient-excess leaf samples (leaf concentrations $=$ and $>$ sufficient values, respectively) were determined using the sufficiency range criterion, and, using the DRIS method, the number of samples with deficient nutrition (DRIS indices $<$ zero and modular DRIS indices $>$ NBIm), with adequate nutrition (DRIS indices $<$ or $=$ NBIm), and with excessive nutrition (DRIS indices $>$ zero and modular DRIS indices $>$ NBIm) (Table 1) were determined.

Table 1. Percentage of data agreement between the criterion of nutrient sufficiency range diagnosis (deficiency, normal, and excess) and the K-DRIS indices calculated according to Beaufils, Jones, and Elwali and Gascho methods, for an apple orchard (Gala cv.) treated with potassium fertilizer (average data of 6 years)

\begin{tabular}{lrrr}
\hline Nutrient & Beaufils & Jones & $\begin{array}{c}\text { Elwali and } \\
\text { Gascho }\end{array}$ \\
\hline $\mathrm{N}$ & 70.83 & 68.06 & 73.61 \\
$\mathrm{P}$ & 68.06 & 58.33 & 81.94 \\
$\mathrm{~K}$ & 65.28 & 62.50 & 70.83 \\
$\mathrm{Ca}$ & 59.72 & 50.00 & 70.83 \\
$\mathrm{Mg}$ & 80.56 & 68.06 & 63.89 \\
$\mathrm{Fe}$ & 86.11 & 97.22 & 95.83 \\
$\mathrm{Mn}$ & 100.00 & 100.00 & 100.00 \\
$\mathrm{Zn}$ & 0.00 & 8.33 & 94.44 \\
$\mathrm{Cu}$ & 81.94 & 54.17 & 93.06 \\
$\mathrm{~B}$ & 87.50 & 84.72 & 81.94 \\
Average & 70.00 & 65.14 & 82.64 \\
\hline
\end{tabular}


Regarding K nutrient diagnosis (the nutrient that was applied in increasing rates in this experiment), the percentage of agreement between the two diagnosis methods was $65.28,62.50$, and $70.83 \%$ for the Beaufils, Jones, and Elwali and Gascho procedures for DRIS index calculation, respectively (Table 1).

The comparison between the sufficiency range criterion and DRIS method for all nutrients showed the highest percentages of agreement when DRIS was calculated by Elwali and Gascho's procedure. Especially for $\mathrm{Zn}, \mathrm{P}, \mathrm{Ca}$, and $\mathrm{Cu}$ low agreement between methods was obtained when DRIS was calculated by Beaufils and Jones equations (Table 1). The Beaufils method resulted in better agreement for $\mathrm{Mg}$ than the other two methods.

\section{CONCLUSIONS}

1. The NBI, calculated from the generated norms, was inversely correlated with the apple fruit productivity and pellicle color.

2. DRIS indices calculated by the method of Elwali and Gascho, based on the sum of functions and using F-values, were the most suitable for the apple orchard studied, because the plant nutritional status and the nutrient diagnosis efficiency were best indicated by the NBI values.

\section{REFERENCES}

Beaufils, E.R. (1973) Diagnosis and Recommendation Integrated System (DRIS): A General Scheme for Experimentation and Calibration Based on Principles Developed from Research in Plant Nutrition (Soil Science Bulletin 1). Pietermararitzburg: University of Natal.

Elwali, A.M.O. and Gascho, G.J. (1984) Soil testing, foliar analysis, and DRIS as guide for sugarcane fertilization. Agronomy. Journal, 76: 466-470.

Ernani, P.R., Dias, J., and Flore, J.A. (2002) Annual additions of potassium to the soil increased apple yield in Brazil. Communications in Soil Science and Plant Analysis, 3: $1291-1304$.

Fallahi, E. and Righetti, T.L. (1984) Use of diagnosis and recommendation integrated system (DRIS) in apple. HortScience, 19: 116.

Freire, C.J.S. (1998) Manual de métodos de análise de tecido vegetal, solo e calcário; Embrapa, CPACT: Pelotas.

Goh, K.M. and Malakouti, M.J. (1992) Preliminary nitrogen, phosphorus, potassium, calcium and magnesium DRIS norms and indices for apple orchards in Canterbury, New Zealand. Communications in Soil Science and Plant Analysis, 23: 1371-1385.

Jones, C.A. (1981) Proposed modifications of the diagnosis and recommendation integrated system (DRIS) for interpreting plant analysis. Communications in Soil Science and Plant Analysis, 12: 785-794.

Letzsch, W.S. (1985) Computer program for selection of norms for use in the diagnosis and recommendation integrated system (DRIS). Communications in Soil Science and Plant Analysis, 16: 339-347. 
Marschner, H. (1995) Mineral Nutrition of Higher Plants, 2nd edn.; Academic Press: London.

Mengel, K. and Kirkby, E.A. (2001) Principles of Plant Nutrition; 5th edn.; Kluwer Academic: Dordrecht, The Netherlands.

Mourão Filho, F.A.A. and Azevedo, J.C. (2003) DRIS norms for "Valencia" sweet orange on three rootstocks. Pesquisa Agropecuária Brasileira, 38: 85-93.

Nachtigall, G.R. (2004) Sistema integrado de diagnose e recomendação (DRIS) para avaliação do estado nutricional da macieira no sul do Brasil. $\mathrm{PhD}$ Thesis, Escola Superior de Agricultura "Luiz de Queiroz," Universidade de São Paulo.

Nachtigall, G.R., Basso, C., and Freire, C.J.S. (2004) Nutrição e adubação de pomares. In Maçã: Produção; Nachtigall, G.R. (ed.); Embrapa Uva e Vinho, Embrapa Informação Tecnológica: Bento Gonçalves, 63-77.

Nick, J.A. (1998) DRIS para cafeeiros podados; Master's Thesis. Escola Superior de Agricultura "Luiz de Queiroz," Universidade de São Paulo.

Parent, L.E. and Granger, R.L. (1989) Derivation of DRIS norms for a high density apple orchard established in the Quebec Appalachian mountains. Journal of the American Society for Horticultural Science, 114: 915-919.

Santos, W.R. (1997) Métodos diagnósticos do equilíbrio nutricional dos macronutrientes em citros. Master's Thesis, Escola Superior de Agricultura "Luiz de Queiroz," Universidade de São Paulo.

SAS Institute. (1985) SAS User's Guide: Statistics, 5th edn.; SAS: Cary., N.C.

Silva, E.B., Nogueira, F.D., and Guimarães, P.T.G. (2003) Uso do DRIS na avaliação do estado nutricional do cafeeiro em resposta à adubação potássica. Revista Brasileira de Ciência do Solo, 27: 247-255.

Singh, N.P., Awasthi, R.P., and Sud, A. (2000) Diagnosis and recommendation integrated system (DRIS) norms for apple (Malus $\times$ Domestica Borkh. L. cv. Starking Delicious) in Himachal Pradesh. Indian Journal of Horticulture, 57: 196-204.

Streck, E.V., Kämpf, N., Dalmolim, R.S.D., Klamt, E., Nascimento, P.C., and Schneider, P. (2002) Solos do Rio Grande do Sul; EMATER/RS, UFRGS: Porto Alegre.

Sumner, M.E. (1986) Diagnosis and Recommendation Integrated System (DRIS) as a Guide to Orchard Fertilization (Athens Extension Bulletin 231). Athens, Ga.: University of Georgia.

Szücs, E. and Kállay, T. (1990) Determination of fruiting capacity of apple trees (Malus domestica) by DRIS. In International Plant Nutrition Colloquium 11; Kluwer Academic Publishers: Dordrecht, The Netherlands, 717-721.

Szücs, E., Kállay, T., and Szenci, G. (1990) Determination of DRIS indices for apple (Malus domestica Borkh). Acta Horticulturae, 274: 443-453.

Wadt, P.G.S. (1996) Os métodos da chance matemática e do sistema integrado de diagnose e recomendação (DRIS) na avaliação nutricional de plantios de eucalipto; $\mathrm{PhD}$ Thesis, Universidade Federal de Viçosa.

Walworth, J.L. and Sumner, M.E. (1987) The diagnosis and recommendation integrated system (DRIS). Advances in Soil Science, 6: 149-188. 